Original Article

\title{
Development and Evaluation of Sunflower Synthetic Varieties (Helianthus annuus L.)
}

\author{
Attia, M. A. ${ }^{1}$, Bakheit B. R. ${ }^{2}$, Abo-Elwafa A. ${ }^{2}$, and El-Shimy A. A. ${ }^{1}$ \\ ${ }^{1}$ Oil Crops Research Department, Field Crops Research Institute, Agriculture Research Centre, Cairo, Egypt. \\ ${ }^{2}$ Agronomy Department, Faculty of Agriculture, Assiut University, Assiut, Egypt.
}

doi:

\section{Abstract}

This study was carried out in the summer seasons of 2010, 2011, 2012 and 2013, respectively, at Shandaweel Agriculture Research Station, Agri. Res. Center. The main objectives of the present investigation are to improve population Giza $_{102}$ of sunflower through development of synthetic varieties by $\mathrm{S}_{1}$ per se family, Half-sib and Top-crosses recurrent selection procedure. In 2013 season, the first cycle of selection (C1) per se, H.S and T.C selection methods were evaluated against the original population $\mathrm{Giza}_{102}$ and check variety Sakha $_{53}$ at Shandaweel and Assiut Agric. Res. Sta. Randomized Complete Block Design (RCBD) with 3 replications were used in the two locations, to measure the actual gain from selection. Data were recorded on days to $50 \%$ flowering, days to maturity, plant height, stalk diameter, head diameter, 100-achene weight, achene yield/plant, achene yield/plot and oil content. Highly significant differences between the two

KEYWORDS

Sunflower,

Helianthus annuus,

$\mathrm{S}_{1}$ selection,

Synthetic varieties,

H.s selection,

Top crosses selection.

\section{CORRESPONDING}

\section{AUTHOR}

Mahrous A. Attia

mahrous.baset@yahoo.com locations were detected for the studied traits. The combined means over two locations of oil content were 42.00, 43.37, 41.37, 39.91 and 39.98 (\%), for $\mathrm{S}_{1}$-cycle. H.S, T.C, original pop. and check variety, respectively. The differences between the three methods selection were significant, except between $S_{1}$ and T.C-cycle was not significant, but the differences between the first cycle selection, original pop. and check variety were significantly increased, except between the T.C-cycle and original pop. and check variety was not significantly increased. With respect to oil content, the observed gain from selection for $\mathrm{S}_{1}$ and H.S family selection methods (5.24\% and 8.67\%), respectively, were higher than those of T.C (3.66\%) selection method. Finally, the $\mathrm{S}_{1}$ per se and H.S selection methods were more effective in improvement the population Giza $_{102}$ of sunflower than the T.C method.

\section{INTRODUCTION}

In some cross-pollinated crops, it has been possible to use hybrid vigor by breeding of synthetic varieties. Synthetic varieties are produce by intercrossing a number of genotypes selected for their general combining ability (Allard 1960; Mayo 1989 and Fehr 1987). The synthetic varieties have several advantages as follows: seed production costs are lower than hybrids, they have high adaptation ability and synthetic varieties may have an important place where commercial acreage is too small for hybrid seed production (Allard 1960). However, one practical disadvantage of synthetics would be lower uniformity than in a single-cross hybrid. The factors considered in the development of a synthetic cultivar include: (a) forming a population, (b) evaluation of parental 
lines, (c) evaluation of the combining abilities of parental lines, (d) test of experimental synthetics and (e) preparation of planting seed that have commercial use (Fehr 1987). Synthetic cultivars sunflower were a desirable alternative to singlecross hybrids when cross-pollination percentage was low and variable (Putt 1962, 1966). The Egyptian sunflower improvement programme aims to combine high oil content, earliness and short stems from foreign germplasm with high yield potential and adaptability of local varieties.

Increasing of oil yield is one of the most important goals in sunflower breeding programs. The superior open-pollinated cultivars so derived must have high self-fertility and oil content, medium plant height, certain level of uniformity for morphological characters, disease and insect resistance and high seed yield. Lokendra and Sheoran (1997), Weginwar et al. (1998) developed and released by recurrent selection PKVSF-9 which was an early maturing variety (8085 ) days. It had $21 \%$ higher seed yields and $22 \%$ higher oil content than Modern. Goksoy (1999) found that the synthetic varieties were superior to the standard varieties in terms of seed yield, seed yield per head, 1000-seed weight and head diameter. Gowda and Seetharam (2008a) found that the response to $S_{1}$ selection was effective only in improving oil content. For other characters including seed yield, the derived populations were inferior compared with the base population, and found that one cycle of $\mathrm{S} 1$ selection was able to improve oil content and oil yield over the base population, as evident from the values of genetic gain.

The objectives of this study were to:

1. Evaluate three methods of selection (i.e. $\mathrm{S}_{1}$ per se, half-sib and test-cross), to improve the oil percentage of the open-pollinated variety Giza $_{102}$ of sunflower;
2. Calculate the observed gain for the first cycle of selection of the three selection methods used.

\section{MATERIALS AND METHODS}

This study was carried out in the summer seasons of 2010, 2011, 2012 and 2013, respectively, at Shandaweel Agriculture Research Station, Agri. Res. Center to study the effect of the three selection methods i.e. $\mathrm{S}_{1}$ per se lines, half-sib and topcrosses population selection methods on yield and its components and actual gain in population Giza $_{102}$ of sunflower.

\section{A- Procedures and field experiment}

The procedures used are out lined below according to the growing season:

\section{Season 2010: Production of top-crosses}

Giza $_{102}$ an open-pollinated of sunflower was shown on June $20^{\text {th }}, 2010$ at Shandaweel Agri. Res. Station. Approximately 100 plants were selected and selfed and tested for general combining ability by top-crossing them to the two testers, $\left(\mathrm{A}_{3}\right.$ and $\mathrm{A}_{21}$ ). After harvest, $23 \mathrm{~S}_{1}$ per se lines and 46 testcrosses, which produced enough seed, were chosen for evaluation in the next season.

\section{Season 2011: Testing for general combining ability}

In this season, two separate yield trials were undertaken. The first experiment included twentythree $S_{1}$ per se lines and Giza ${ }_{102}$ and the second trial included the 46 top-crosses and the two testers $\left(\mathrm{B}_{3}\right.$ and $\mathrm{B}_{21}$ ). In both trials; The Randomized Complete Block Design (RCBD) with three replications was used, the plot size was 1 row with 4 meter long and $60 \mathrm{~cm}$ apart. Planting was done in hills spaced 25 $\mathrm{cm}$ apart. Seedlings were thinned to one plant per hill before the first irrigation (two weeks after planting). The cultural practices followed the recommendation for oil seed sunflower production. 
At harvest, the oil percentage was determined in the all genotypes.

\section{Season 2012: Production of synthetic varieties a. Production of synthetic I (per se)}

In the early summer on March $1^{\text {st }} 2012$ and as a result of the 2011 season oil percentage, the highest ten lines in absolute mean were selected, namely; $\mathrm{S}_{17}, \mathrm{~S}_{15}, \mathrm{~S}_{11}, \mathrm{~S}_{7}, \mathrm{~S}_{21}, \mathrm{~S}_{18}, \mathrm{~S}_{20}, \mathrm{~S}_{16}, \mathrm{~S}_{1}$ and $\mathrm{S}_{14}$. From these lines, the synthetic variety I was produced by mixing thorough forty seeds from each inbred line. This mixture was planted in an isolated plot to produce the synthetic I seeds.

\section{b. Production of synthetic II (H.S)}

On April $1^{\text {st }} 2012$, as a results of the 2011 season yield trials the highest ten lines in combining ability in oil percentage were selected, namely; $\mathrm{S}_{15}$, $\mathrm{S}_{23}, \mathrm{~S}_{13}, \mathrm{~S}_{5}, \mathrm{~S}_{3}, \mathrm{~S}_{17}, \mathrm{~S}_{1}, \mathrm{~S}_{8}, \mathrm{~S}_{11}$ and $\mathrm{S}_{7}$. From these lines, the synthetic variety II was produced by mixing thorough fourty seeds from each inbred line. This mixture was planted in an isolated plot to produce the synthetic II seeds.

\section{c. Production of synthetic III (Top crosses)}

On May $1^{\text {st }} 2012$ as a result of oil percentage the highest ten top-crosses in specific combining ability were selected, namely; top-cross (1x2),

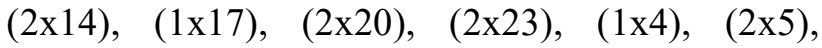
$(2 \times 15),(1 \times 3)$ and $(1 \times 8)$. From these top-crosses, the synthetic variety III was produced by mixing thorough forty seeds from each top-cross. This mixture was planted in an isolated plot to produce the synthetic III seeds.

The three groups of the selected synthetic were planted in non-replicated plots at Shandaweel Agric. Res. Station. The plot size was 40 rows, $4 \mathrm{~m}$ length, $60 \mathrm{~cm}$ apart and $25 \mathrm{~cm}$ between hills within a row. At 50\% flowering, pollen grains were collected from all plant in each plot and pulked. The pulked pollen grains of a plot were used to pollinate the plants of the same plot. Pollinated heads from each breeding methods were harvested, dried and threshed together to for the first cycle seeds.

\section{Season 2013: performance of synthetic varieties}

In 2013-summer season, the first cycle of selection (C1); Per se. H.s and Top-crosses population, against the original population Giza $_{102}$, in addition to the check variety Sakha 53 were evaluated at Shandaweel Agric. Res. Sta. on $6^{\text {th }}$ July, 2013 and Assiut Agric. Res. Sta. on $8^{\text {th }}$ July, 2013 to measure the actual gain from selected. Randomized Complete Block Design (RCBD) with three replications was used in the two locations. The plot size was 4 rows, 4 meter long and $60 \mathrm{~cm}$ apart. Planting was done in hills spaced $25 \mathrm{~cm}$ apart. Seedlings were thinned to one plant per hill before the first irrigation (two weeks after planting in both locations). Normal agricultural practices were applied as recommendation for oil seed sunflower production.

\section{B- The studied characters}

The traits studied could be divided as follows:

\section{a. Earliness traits}

1) Days to $50 \%$ flowering: number of days from sowing date to appearance of heads $50 \%$ of plants.

2) Days to maturity: was measured as number of days from sowing date until all heads became yellow on plot basis.

\section{b. Growth traits:}

The following traits were taken from random sample of five guarded plants from each plot and assigned to be fixed for the following measurements:

1) Plant height, $\mathrm{cm}$ : average length in $\mathrm{cm}$ from soil level to the tip of the head.

2) Stalk diameter, $\mathrm{cm}$ : measured at $30 \mathrm{~cm}$ above the soil surface with vernier-calipers, at nearest $0.1 \mathrm{~cm}$. 
3) Head diameter, cm: estimated as an average of maximum width of the head.

\section{c. Yield and yield components:}

1) Achene yield/plant, g: estimated as average of seed weight/head.

2) Achene yield/plot, g: measured from the adjusted seed yield/plot.

3) 100-achene weight, g: One hundred seed were counted and weighed from the bulk of the guarded plants in grams.

4) Oil content: random sample of seeds were taken from the seed yield of the five guarded plants. The oil content was determined by soxalet apparatus using petroleum ether $\left(\mathrm{Bp} 40-60 \mathrm{c}^{\mathrm{o}}\right)$ as solvent according to the official method (A. O. A. C. 1980).

\section{C- Statistical analysis}

\section{Evaluation of the first cycles of selection}

The first cycle $(\mathrm{C} 1)$ resulted from selection method were analyzed for each of the two locations and combined over locations in Table 1.

Table (1) The form of the analysis of variance for evaluation trial for a single and combined over locations.

\begin{tabular}{|l|c|c|}
\hline \multirow{2}{*}{\multicolumn{1}{|c|}{ S.O.V }} & \multicolumn{2}{c|}{ D.F } \\
\cline { 2 - 3 } & Single & Combined \\
\hline Locations (L) & - & $(1-1)$ \\
\hline Rep/L & - & $1(\mathrm{r}-1)$ \\
\hline Replications & $(\mathrm{r}-1)$ & - \\
\hline Genotypes & $(\mathrm{g}-1)$ & $(\mathrm{g}-1)$ \\
\hline Error & $(\mathrm{r}-1)(\mathrm{g}-1)$ & - \\
\hline G x L & - & $(\mathrm{l}-1)(\mathrm{g}-1)$ \\
\hline Error & - & $1(\mathrm{~g}-1)(\mathrm{r}-1)$ \\
\hline
\end{tabular}

\section{RESULTS AND DISCUSSION}

\section{Evaluation of the first cycle populations for the three selection methods}

Mean squares of yield, it's component and some other traits of synthetic varieties derived from the selected $\mathrm{S}_{1}$ lines using two methods of selection; per se and H.S, selected $\mathrm{F}_{1}$ top-crosses using topcrosses selection method, along with their original population of Giza $_{102}$ and check variety under the two locations are shown in Table (2).

Significant differences were recorded for all the studied traits of the evaluated populations under the two locations, Shandaweel and Assiut.

Combined mean squares over two locations for yield, its component and some related traits of the 1 st cycle for three selection methods are shown in Table (3). Highly significant differences between the two locations were detected for the studied traits. Mean squares of populations for all studied traits were highly significant.

These results indicate the presence of differences among the populations (cycle-1). On the other hand, the populations $\mathrm{x}$ locations interaction were non-significant in all the studied traits.

\section{I.1. Mean performance of selected population}

Mean performance for yield, its component and other agronomic traits of the evaluated populations of cycle-1 for three selection methods (C1) under the two locations and combined over the two locations are listed in Table 4 and 5, respectively.

\section{I.1.1. Days to 50 \% flowering}

At Shandaweel, the average values of days to 50 $\%$ flowering (Table 4), were 47.33, 48.67, 50.33, 47.67 and 54.33 days for $\mathrm{S}_{1}$-cycle, H.S, T.C, original population and check variety $\mathrm{Sakha}_{53}$, respectively. The first cycle of selection for T.C was significantly later than the original population

At Assiut, the averages were 43.33, 44.00, 46.67, 44.33 and 50.67 days for $\mathrm{S}_{1}$-cycle, H.S, T.C, original pop. and check variety, respectively. The first cycle of selection for H.S was earlier insignificant than the original pop. Generally, all studied populations were earlier at Assiut than Shandaweel (Table 4), revealing the G x E effect.

The combined mean days to $50 \%$ flowering over the two locations (Table 5) were 45.33, 46.34, 
48.50, 46.00 and 52.50 days for $\mathrm{S}_{1}$-cycle, H.S, T.C, original pop. and check variety, respectively. The first cycle was later significantly for T.C and insignificant for H.S than the original pop. Otherwise, $S_{1}$ cycle was insignificant earlier. This results revealed that the different genetic makeup for obtained selections from different methods. Generally, the first cycle was significantly earlier than the check variety for all three methods selection.

Table (2) Mean squares of the studied traits for the $1^{\text {st }}$ cycle populations under the two locations Shandaweel and Assiut.

\begin{tabular}{|c|c|c|c|c|c|c|c|c|c|c|}
\hline \multirow[b]{2}{*}{ S.O.V } & \multirow[b]{2}{*}{ D.F } & \multicolumn{9}{|c|}{ M.S. } \\
\hline & & $\begin{array}{c}\text { Days to } \\
50 \% \\
\text { flowering }\end{array}$ & $\begin{array}{l}\text { Days to } \\
\text { maturity }\end{array}$ & $\begin{array}{l}\text { Plant } \\
\text { height } \\
(\mathrm{cm})\end{array}$ & \begin{tabular}{|c} 
Stalk \\
diameter \\
$(\mathrm{cm})$
\end{tabular} & $\begin{array}{c}\text { Head } \\
\text { diameter } \\
(\mathrm{cm}) \\
\end{array}$ & $\begin{array}{c}\text { 100-achene } \\
\text { weight } \\
\text { (g) }\end{array}$ & $\begin{array}{c}\text { Achene } \\
\text { yield/plant } \\
\text { (g) }\end{array}$ & $\begin{array}{c}\text { Achene } \\
\text { yield/plot } \\
\text { (g) }\end{array}$ & $\begin{array}{c}\text { Oil } \\
\text { content } \\
(\%)\end{array}$ \\
\hline \multicolumn{11}{|c|}{ Shandaweel } \\
\hline Rep. & 2 & 4.47 & 0.87 & 22.87 & 0.005 & 0.18 & 0.17 & 4.45 & 9008.39 & 0.45 \\
\hline Populations & 4 & $24.50 * *$ & $17.10^{* *}$ & $398.10 * *$ & $0.195 * *$ & $6.85 * *$ & $1.50 * *$ & $81.72 * *$ & $165472.47 * *$ & $7.58 * *$ \\
\hline Error & 8 & 1.55 & 1.70 & 27.70 & 0.007 & 0.88 & 0.35 & 4.69 & 9503.63 & 0.28 \\
\hline \multicolumn{11}{|c|}{ Assiut } \\
\hline Rep. & 2 & 1.40 & 0.87 & 29.07 & 0.007 & 0.22 & 0.08 & 1.78 & 10910.21 & 0.38 \\
\hline Populations & 4 & $26.93 * *$ & $20.43 * *$ & $401.60 * *$ & $2.127 * *$ & $4.68 * *$ & $0.33 * *$ & $49.40 * *$ & $104698.22 * *$ & $5.37 * *$ \\
\hline Error & 8 & 1.73 & 1.53 & 18.15 & 0.003 & 0.45 & 0.21 & 2.21 & 3439.65 & 0.19 \\
\hline
\end{tabular}

** Highly significant at $1 \%$ levels of probability.

Table (3) Combined analysis of the studied traits for the $1^{\text {st }}$ cycle populations in sunflower synthetic varieties over two location.

\begin{tabular}{|c|c|c|c|c|c|c|c|c|c|c|}
\hline \multirow[b]{2}{*}{ S.O.V } & \multirow[b]{2}{*}{ D.F } & \multicolumn{9}{|c|}{ M.S. } \\
\hline & & \begin{tabular}{|c|} 
Days to \\
$50 \%$ \\
flowering \\
\end{tabular} & $\begin{array}{l}\text { Days to } \\
\text { maturity }\end{array}$ & $\begin{array}{c}\text { Plant } \\
\text { height } \\
(\mathrm{cm})\end{array}$ & $\begin{array}{c}\text { Stalk } \\
\text { diameter } \\
(\mathrm{cm}) \\
\end{array}$ & $\begin{array}{c}\text { Head } \\
\text { diameter } \\
(\mathrm{cm})\end{array}$ & $\begin{array}{c}\text { 100-achene } \\
\text { weight } \\
\text { (g) }\end{array}$ & $\begin{array}{c}\text { Achene } \\
\text { yield/plant } \\
\text { (g) }\end{array}$ & $\begin{array}{c}\text { Achene } \\
\text { yield/plot } \\
\text { (g) }\end{array}$ & $\begin{array}{c}\text { Oil } \\
\text { content } \\
(\%) \\
\end{array}$ \\
\hline Locations (L) & 1 & $112.13 * *$ & $187.50 * *$ & $12772.03 * *$ & $3.605 * *$ & $232.97 * *$ & $59.08 * *$ & $5055.19 * *$ & $9979620.60 * *$ & $5.11 * *$ \\
\hline $\operatorname{Rep} / \mathbf{L}$ & 4 & 2.93 & 0.87 & 25.97 & 0.006 & 0.20 & 0.12 & 3.16 & 9959.30 & 0.42 \\
\hline Genotype (G) & 4 & $51.05 * *$ & $37.37 * *$ & $742.75^{* *}$ & $0.289 * *$ & $11.39 * *$ & $1.59 * *$ & $127.80 * *$ & $265723.63^{* *}$ & $12.69 * *$ \\
\hline$G \times L$ & 4 & 0.38 & 0.17 & 56.95 & 0.033 & 0.14 & 0.25 & 3.31 & 4447.05 & 0.25 \\
\hline Error & 16 & 1.64 & 1.62 & 22.93 & 0.005 & 0.66 & 0.28 & 3.45 & 6471.64 & 0.24 \\
\hline
\end{tabular}

** Highly significant at $1 \%$ levels of probability.

\section{I.1.2. Days to maturity}

At Shandaweel, The averages of days to maturity (Table 4) were $78.00,80.33,78.33,80.00$ and 84.00 days for $\mathrm{S}_{1}$ cycle H.S, T.C, original pop and check variety, respectively. At Assiut, the averages were $73.00,75.67,73.00,74.67$ and 79.33 days for $\mathrm{S}_{1}$ cycle, H.S, T.C, original pop. and check variety, respectively. The first cycles of selection were earlier than the original pop. except H.S under the two locations. Generally, the average of maturity at Assiut was earlier than Shandaweel area.

Averages of days to maturity over the two locations (Table 5) were 75.50, 78.00, 75.67, 77.34 and 81.67 days for S1-cycle, H.S, T.C, original pop. and the check variety, respectively. The first cycles for all the three methods selection was 
earlier than the original pop. except H.S cycle was for all the three methods selection were later than the original pop. Whereas, the first cycle significantly earlier than the check variety.

Table (4) Mean performance of the studied traits for the $1^{\text {st }}$ cycle populations in sunflower synthetic varieties for three selection methods at Shandaweel and Assiut locations.

\begin{tabular}{|c|c|c|c|c|c|c|c|c|c|c|}
\hline Population & $\begin{array}{l}\text { Selection } \\
\text { methods }\end{array}$ & $\begin{array}{c}\text { Days to } \\
50 \% \\
\text { flowering }\end{array}$ & $\begin{array}{l}\text { Days to } \\
\text { maturity }\end{array}$ & $\begin{array}{c}\text { Plant } \\
\text { height } \\
\text { (cm) }\end{array}$ & $\begin{array}{c}\text { Stalk } \\
\text { diameter } \\
(\mathrm{cm})\end{array}$ & $\begin{array}{c}\text { Head } \\
\text { diameter } \\
(\mathrm{cm})\end{array}$ & $\begin{array}{c}100- \\
\text { achene } \\
\text { weight } \\
(\mathrm{g})\end{array}$ & $\begin{array}{c}\text { Achene } \\
\text { yield/plant } \\
\text { (g) }\end{array}$ & $\begin{array}{c}\text { Achene } \\
\text { yield/plot } \\
\text { (g) }\end{array}$ & $\begin{array}{c}\text { Oil } \\
\text { content } \\
(\%)\end{array}$ \\
\hline \multicolumn{11}{|c|}{ Shandaweel } \\
\hline Synthetic 1 & $\mathrm{~S}_{1}$ & 47.33 & 78.00 & 176.33 & 2.21 & 22.40 & 8.88 & 80.43 & 3619.20 & 42.58 \\
\hline Synthetic 2 & H.S & 48.67 & 80.33 & 190.33 & 2.38 & 18.87 & 7.70 & 77.27 & 3477.30 & 43.81 \\
\hline Synthetic 3 & Top. C & 50.33 & 78.33 & 200.33 & 2.15 & 20.27 & 7.53 & 73.33 & 3299.70 & 41.97 \\
\hline \multicolumn{2}{|c|}{ Original } & 47.67 & 80.00 & 171.33 & 1.90 & 19.60 & 6.93 & 67.36 & 3031.20 & 40.22 \\
\hline \multicolumn{2}{|c|}{ Check } & 54.33 & 84.00 & 187.33 & 2.58 & 21.93 & 7.68 & 78.75 & 3543.87 & 40.09 \\
\hline \multicolumn{2}{|c|}{ L.S.D’0.05 } & 1.15 & 1.20 & 4.86 & 0.08 & 0.87 & 0.55 & 2.00 & 90.07 & 0.49 \\
\hline \multicolumn{11}{|c|}{ Assiut } \\
\hline Synthetic 1 & $\mathrm{~S}_{1}$ & 43.33 & 73.00 & 133.67 & 1.40 & 16.53 & 5.49 & 54.37 & 2446.80 & 41.40 \\
\hline Synthetic 2 & H.S & 44.00 & 75.67 & 145.67 & 1.75 & 13.53 & 4.82 & 49.75 & 2312.40 & 42.93 \\
\hline Synthetic 3 & Top. C & 46.67 & 73.00 & 153.33 & 1.37 & 15.00 & 4.72 & 47.89 & 2155.05 & 40.76 \\
\hline \multicolumn{2}{|c|}{ Original } & 44.33 & 74.67 & 130.33 & 1.44 & 14.13 & 4.67 & 43.62 & 1962.75 & 39.60 \\
\hline \multicolumn{2}{|c|}{ Check } & 50.67 & 79.33 & 156.33 & 1.80 & 16.00 & 5.00 & 51.70 & 2326.65 & 39.86 \\
\hline \multicolumn{2}{|c|}{ L.S.D' 0.05} & 1.22 & 1.14 & 3.94 & 0.05 & 0.62 & 0.42 & 1.37 & 54.19 & 0.40 \\
\hline
\end{tabular}

Table (5) Combined mean performance of the studied traits for the 1st cycle populations in three sunflower synthetic varieties for three selection methods over two location.

\begin{tabular}{|c|c|c|c|c|c|c|c|c|c|c|}
\hline Populations & $\begin{array}{c}\text { Selection } \\
\text { methods }\end{array}$ & $\begin{array}{c}\text { Days to } \\
\mathbf{5 0 \%} \\
\text { flowering }\end{array}$ & $\begin{array}{c}\text { Days to } \\
\text { maturity }\end{array}$ & $\begin{array}{c}\text { Plant } \\
\text { height } \\
\mathbf{( c m )}\end{array}$ & $\begin{array}{c}\text { Stalk } \\
\text { diameter } \\
\mathbf{( c m )}\end{array}$ & $\begin{array}{c}\text { Head } \\
\text { diameter } \\
\mathbf{( c m )}\end{array}$ & $\begin{array}{c}\text { 100-achene } \\
\text { weight } \mathbf{( g )}\end{array}$ & $\begin{array}{c}\text { Achene } \\
\text { yield/plant } \\
\mathbf{( g )}\end{array}$ & $\begin{array}{c}\text { Achene } \\
\text { yield/plot } \\
\mathbf{( g )}\end{array}$ & $\begin{array}{c}\text { Oil } \\
\text { content } \\
\mathbf{( \% )}\end{array}$ \\
\hline Synthetic 1 & $\mathbf{S}_{\mathbf{1}}$ & 45.33 & 75.50 & 155.00 & 1.81 & 19.47 & 7.20 & 67.40 & 3033.00 & 42.00 \\
\hline Synthetic 2 & H.S & 46.34 & 78.00 & 168.00 & 2.07 & 16.20 & 6.26 & 63.51 & 2894.85 & 43.37 \\
\hline Synthetic 3 & Top. C & 48.50 & 75.67 & 176.83 & 1.76 & 17.64 & 6.13 & 60.61 & 2727.38 & 41.37 \\
\hline Original & 46.00 & 77.34 & 150.83 & 1.67 & 16.87 & 5.80 & 55.49 & 2496.98 & 39.91 \\
\hline Check & 52.50 & 81.67 & 171.83 & 2.19 & 18.97 & 6.34 & 65.23 & 2935.26 & 39.98 \\
\hline L.S.D' 0.05 & 1.18 & 1.18 & 4.42 & 0.07 & 0.75 & 0.49 & 1.72 & 74.33 & 0.45 \\
\hline
\end{tabular}

\section{I.1.3. Plant height (cm)}

For plant height, the average plant heights at Shandaweel (Table 4) were 176.33, 190.33, 200.33, 171.33 and $187.33 \mathrm{~cm}$, for $\mathrm{S}_{1}$, cycle, H.S, T.C, original pop. and the check variety, respectively. The differences between the three methods were significant, but plant height of $\mathrm{S} 1$ insignificantly increased than the original pop. Whereas, the $S_{1}$ cycle was significantly decreased than the check variety, while the H.S, T.C were increased than the check variety.

At Assiut, the average plant height of the first $\mathrm{S}_{1}$-cycle, H.S, T.C, original pop. and the check variety were, 133.67, 145.67, 153.33, 130.33 and $156.33 \mathrm{~cm}$, respectively. These data were short 
compared to Shandaweel location. The differences between the three methods were significant, but the $\mathrm{S}_{1}$ cycle was insignificantly increased and the H.S, T.C cycle were significantly increased than the original pop. While the three cycle selection were significantly increased than the check variety, except the T.C cycle was not significantly increase.

The combined means over two locations of plant height (Table 5) were 155.00, 168.00, 176.83, 150.83 and $171.83 \mathrm{~cm}$, for the first S1 cycle, H.S, T.C, original pop. and the check variety, respectively, the difference between the three methods selection was significant and between the first cycle and original pop. was significant increased except $S_{1}$ cycle was not significant increased. While, compared to $\mathrm{Sakha}_{53}$, the $\mathrm{S}_{1}$ cycle was significant decreased and the H.S cycle was not significant decreased and the T.C cycle was not significant increased than the check variety.

\section{I.1.4. stalk diameter (cm)}

Average stalk diameter at Shandaweel (Table 4) of the first cycle were 2.21, 2.38, 2.15, 1.90 and $2.58 \mathrm{~cm}$, for $\mathrm{S}_{1}$-cycle, H.S, T.C, original pop. and check variety, respectively. At Assiut, average stalk diameter were less and recorded 1.40, 1.75, 1.37, 1.44 and $1.80 \mathrm{~cm}$, for $\mathrm{S}_{1}$-cycle, H.S, T.C, original pop. and check variety, respectively.

Combined means over locations of stalk diameter (Table 5) were 1.81, 2.07, 1.76, 1.67 and $2.19 \mathrm{~cm}$, for $\mathrm{S}_{1}$-cycle, H.S, T.S, original pop. and check variety, respectively. The first cycle of selection were significantly increased than the original pop., except the T.C-cycle was not significantly increased. While the first cycle and the check varieties were significantly decreased. The differences between the $\mathrm{S}_{1}$-cycle and H.S was significant, $\mathrm{S}_{1}$-cycle and T.C was not significant, and between H.S-cycle and T.C was significant.

\section{I.1.5. Head diameter (cm)}

For head diameter (Table 4) At Shandaweel, the averages of the first cycle were 22.40, 18.87, 20.27,
19.60 and $21.93 \mathrm{~cm}$, for $\mathrm{S}_{1}$-cycle, H.S, T.C, original pop. and check variety, respectively. At Assiut, average head diameter were low compared to Shandaweel and recorded 16.53, 13.53, 15.00, 14.13 and $16.00 \mathrm{~cm}$, for the $S_{1}$-cycle, H.S, T.C, original pop. and check variety, respectively.

Combined means over two locations of head diameter (Table 5) were 19.47, 16.20, 17.64, 16.87 and $18.97 \mathrm{~cm}$, for $\mathrm{S}_{1}$ cycle, H.S, T.C, original pop. and check variety, respectively. The differences between the first cycle of the three methods selection and between the $\mathrm{S}_{1}$-cycle and original pop. was significant, but the head diameter of H.Scycle was not significant decreased, whereas T.Ccycle was not significant increased. On the other hand, the first cycle of $S_{1}$ was not significant increased, but H.S and T.C cycle were significant and not significant decreased, respectively, than the check variety.

\section{I.1.6. 100-achene weight (g)}

Regarding to 100 -achene weight, at Shandaweel (Table 4) the averages were 8.88, 7.70, 7.53, 6.93 and 7.68 , g. for $\mathrm{S}_{1}$-cycle, H.S, T.C, original pop. and check variety, respectively. The differences between the three methods was significant, except between the first cycle H.S-cycle and T.C, but the 100 -achene weight of the three cycle selection were insignificantly increased than the original pop. except the first $\mathrm{S}_{1}$-cycle was significant increased. While, compared to the check variety and the first $\mathrm{S}_{1}$-cycle was significant increased, but the H.Scycle was insignificant increased, whereas the T.Ccycle was insignificant decreased than the check variety. At Assiut, the averages were less and accounted 5.49, 4.82, 4.72, 4.67 and 5.00, g. for $\mathrm{S}_{1^{-}}$ cycle, H.S, T.C, original pop. and check variety, respectively. The differences between the three methods selection was not significant, except between the first $\mathrm{S}_{1}$-cycle and T.C, but the 100achene weight of the three cycle selection were not significant increased than the original pop., except the first $\mathrm{S}_{1}$-cycle was significantly increased. 
While, the first $\mathrm{S}_{1}$-cycle was significantly increased than the check variety, whereas the first H,S and T.S cycle were not significantly decreased.

The combined means over two locations of 100achene weight (Table 5) were 7.20, 6.26, 6.13, 5.80 and 6.34, g. for $\mathrm{S}_{1}$-cycle, H.S, T.C, original pop. and check variety, respectively. The differences between the three methods selection were significant, except between the H.S and T.C-cycle were not significant, but 100 -achene weight of the three cycle selection were not significantly increased than the original pop., except the $\mathrm{S}_{1}$-cycle was significantly increased. On the other side, the differences between the first $\mathrm{S}_{1}$-cycle and the check variety were not significantly increased, whereas the H.S and T.C-cycle were not significantly decreased than the check variety.

\section{I.1.7. Achene yield/plant (g)}

With respect to achene yield/plant (Table 4) At Shandaweel, the averages were $80.43,77.27,73.33$, 67.36 and $78.75, \mathrm{~g} /$ plant for $\mathrm{S}_{1}$-cycle, H.S, T.C, original pop. and check variety, respectively. The differences between the three methods selection and between the first cycle and original pop. was significant. While, the differences between the first $\mathrm{S}_{1}$-cycle and the check variety was significant, whereas between check variety and H.S-cycle was not significant, but was significant for the first T.Ccycle.

At Assiut, the averages were 54.37, 49.75, $47.89,43.62$ and 51.70, g/plant for the first $S_{1}$ cycle, H.S, T.C, original pop. and check variety, respectively. The differences between the three methods selection was significant, except between H.S and T.C-cycle was insignificant, but the differences between the first cycle and original pop. was significantly increased. On the other hand, the differences between the first $\mathrm{S}_{1}$-cycle and the check variety was significantly increased, but was not significantly decreased for H.S and was significantly decreased for T.C-cycle than the check variety.
The combined means of achene yield/plant over two locations (Table 5) were 67.40, 63.51, 60.61, 55.49 and 65.23, g/plant $\mathrm{S}_{1}$-cycle, H,S, T.C, original pop. and the check variety, respectively. The differences between the first cycle and the original pop. and between the three methods was significantly increased. On the other side, the differences between the first $S_{1}$-cycle and check variety was not significantly increased, but was not significantly decreased for H.S-cycle and was significantly decreased for T.C-cycle than the check variety.

\section{I.1.8. Achene yield/plot (g)}

With respect to achene yield/plot at Shandaweel, (Table 4) averages achene yield/plot of the first cycle were $3619.20,3477.30,3299.70,3031.20$ and 3543.87, g/plot for $\mathrm{S}_{1}$ per se, H.S, T.C, original pop. and check variety, respectively. The differences between the three methods were significant, except between the first $\mathrm{S}_{1}$-cycle and T.C, but the yield of the first cycle of three methods significantly out-yielded the base pop. While the differences between the first $\mathrm{S}_{1}$-cycle and the check variety was not significant increased, but was not significantly decreased for H.S, whereas significantly decreased for the T.C-cycle than the check variety. These results indicating the method of $\mathrm{S}_{1}$ per se was more effective for improving the population than H.S method because this method improves the general combining ability and selection for additive gene effect.

At Assiut, the less average achene yield/plot (Table 4) were 2446.80, 2312.40, 2155.05, 1962.75 and $2326.65, \mathrm{~g} / \mathrm{plot}$ for the first $\mathrm{S}_{1}$-cycle, H.S, T.C, original pop. and the check variety, respectively. The differences between the three methods and the yield of the first cycle for the three methods and the base pop. were significant. While, the first $\mathrm{S}_{1}$-cycle significantly out-yielded the check variety, but the differences between the yield of the H.S-cycle was not significantly decreased. Whereas, the difference 
between T.C-cycle and the check variety was significantly decreased.

The combined mean achene yield/plot over two locations (Table 5) was 3033.00, 2894.85, 2727.38, 2496.98 and 2935.26, g/plot for the first $\mathrm{S}_{1}$-cycle, H.S, T.C, original pop. and the check variety, respectively. The differences between the three methods and between the first cycle and original pop. was significant. On the other hand, the difference between the first $\mathrm{S}_{1}$-cycle and the check variety was not significantly increased, but was significantly decreased for T.C-cycle and was not significantly decreased for H.S-cycle than the check variety.

Generally, the method of selection of $\mathrm{S}_{1}$ per se was more effective than H.S method because it depends upon the general than specific combining ability and utilized more additive than non-additive genetic variance and that H.S method selection depends upon the specific combining ability and utilizes more non-additive variance. These results were in harmony with the results of Lokendra and Sheoran (1997). Goksoy (1999) found that the synthetic varieties were superior to the standard varieties in terms of seed yield, seed yield per head, 1000-seed weight and head diameter (Goksoy \& Turan 2000, Lokendra et al. 2000 and Seneviratne et al. 2004b).

\section{I.1.9. Oil content (\%)}

Regarding to oil content, at Shandaweel (Table 4) the averages were $42.58,43.81,41.97,40.22$ and 40.09 , (\%) for $\mathrm{S}_{1}$-cycle, H.S, T.C, original pop. and the check variety, respectively. The differences between the three methods were significant, except between $S_{1}$ and T.C-cycle were not significant, but the oil content of the first cycle selection were significant increased than the original pop. and the check variety.

At Assiut, average oil content were 41.40, 42.93, 40.76, 39.60 and 39.86, (\%) for $\mathrm{S}_{1}$-cycle, H.S, T.C, original pop. and the check variety, respectively.
The combined means over two locations of oil content (Table 5) were 42.00, 43.37, 41.37, 39.91 and $39.98(\%)$, for $\mathrm{S}_{1}$-cycle. H.S, T.C, original pop. and check variety, respectively. The differences between the three methods selection were significant, except between $S_{1}$ and T.C-cycle was not significant, but the differences between the first cycle selection, original pop. and check variety were significantly increased, except between the T.C-cycle and original pop. and check variety was not significantly increased. These results that $S_{1}$ per se selection method was more effective than H.S and T.C methods in improving the population Giza $_{102}$ of sunflower. It's reasonable to expect that $\mathrm{S}_{1}$ performance should reflect mainly additive genetic effects, while H.S and T.C performance should reflect some non-additive effects as well due to dominance or epistasis relationships between the evaluated parent and tester. Yadav et al. (2004), Seneviratne et al. (2004b) and Syed et al. (2004) found correlated response to $S_{1}$ selection for yield and yield components indicated that indirect selection for achene yield and oil yield was effective. Khulbe et al. (2005), Gowda \& Seetharam (2008a) found that the response to $S_{1}$ selection was effective only in improving oil content. For other characters including seed yield, the derived populations were inferior compared with the base population, and found that one cycle of $\mathrm{S}_{1}$ selection was able to improve oil content and oil yield over the base population, as evident from the values of genetic gain (Gowda \& Seetharam 2008b). All these reports are in agreement with the present study.

\section{I.2. The observed gain from selection}

Observed gain per cycle for yield and its components in addition to days to $50 \%$ flowering and days to maturity under the three selection methods ( $\mathrm{S}_{1}$ line per se, half-sibs and Top-crosses) are shown in Table (6).

The observed gain from selection for days to $50 \%$ flowering of $\mathrm{S} 1$ selection method was (- 
$1.46 \%)$ compared to $(0.74 \%$ and $5.43 \%)$ for H.S and T.C family selection, respectively.

Observed gain from selection for days to maturity of $\mathrm{S}_{1}$ selection method was $(-2.38 \%)$ compared to $(0.85 \%$ and $-2.16 \%)$ for H.S and T.C family selection, respectively. Regarding to head diameter, the observed gain for S1 family selection method $(15.47 \%)$ were higher than those of halfsibs $(-3.97 \%)$ and T.C selection methods (4.56\%). With respect of 100-achene weight, the observed gain for $\mathrm{S}_{1}$ family selection method was $24.14 \%$ higher than of H.S and T.C selection methods $(7.93 \%$ and $5.69 \%)$, respectively.

Table (6) Observed gain $\%$ from the first cycle of $\mathrm{S}_{1}$-line, half-sib and top cross selections in three sunflower synthetic varieties over two locations.

\begin{tabular}{|c|c|c|c|c|c|c|c|c|}
\hline \multirow[t]{2}{*}{ Populations } & \multirow[t]{2}{*}{$\begin{array}{l}\text { Selection } \\
\text { methods }\end{array}$} & $\begin{array}{c}\text { Days to } \\
50 \% \\
\text { flowering }\end{array}$ & $\begin{array}{l}\text { Days to } \\
\text { maturity }\end{array}$ & $\begin{array}{c}\text { Head } \\
\text { diameter } \\
(\mathrm{cm})\end{array}$ & $\begin{array}{l}\text { 100-achene } \\
\text { weight } \\
\text { (g) }\end{array}$ & $\begin{array}{c}\text { Achene } \\
\text { yield/plant } \\
\text { (g) }\end{array}$ & $\begin{array}{c}\text { Achene } \\
\text { yield/plot } \\
\text { (g) }\end{array}$ & $\begin{array}{c}\text { Oil } \\
\text { Content } \\
(\%)\end{array}$ \\
\hline & & Ac. $\%$ & Ac. $\%$ & Ac. $\%$ & Ac. $\%$ & Ac. $\%$ & Ac. $\%$ & Ac. $\%$ \\
\hline Synthetic 1 & $S_{1}$ & -1.46 & -2.38 & 15.41 & 24.14 & 21.46 & 21.47 & 5.24 \\
\hline Synthetic 2 & H.S & 0.74 & 0.85 & -3.97 & 7.93 & 14.45 & 15.93 & 8.67 \\
\hline Synthetic 3 & Top. C & 5.43 & -2.16 & 4.56 & 5.69 & 9.23 & 9.23 & 3.66 \\
\hline
\end{tabular}

Gain percentage based on the original $(\mathrm{C} 0)$.

Observed gain from selection for achene yield/plant of $S_{1}$ family selection method (21.46\%) was higher than those of H.S and T.C selection methods (14.45\% and $9.23 \%$ ), respectively.

Regarding to achene yield/plot, the observed gain from selection of $S_{1}$ family selection method $(21.46 \%)$ was higher than those of H.S and T.C selection methods $(15.93 \%$ and $9.23 \%)$, respectively. The same trend was obtained as achene yield/plant. Indicating that the three methods of $\mathrm{S}_{1}$ line per se, H.S, and T.C recurrent selection can be used to intra-population improvement.

With respect to oil content, the observed gain from selection for $S_{1}$ and H.S family selection methods $(5.24 \%$ and $8.67 \%)$, respectively, were higher than those of T.C (3.66\%) selection method. These results indicated that the observed gain for $S_{1}$ line and H.S methods was more than those of T.C method and this could be due to that the $S_{1}$ lines and H.S selected depended upon the additive and the T.C depended upon mainly the non-additive and epistasis.
Finally, the $\mathrm{S}_{1}$ per se and H.S selection methods were more effective in improvement the population than the T.C method. Shabana (1990) found after 1 cycle of recurrent selection, 6 sub-populations were obtained for further improvement. Luduena $\boldsymbol{e t}$ al. (1992), Biswas et al. (1996) found a high relative efficiency was recorded when plant height, head diameter, seeds/head, 1000-seed weight and seed yield/plant were selected together. Lokendra et al. (1997), Weginwar et al. (1998) Developed by recurrent selection and released, PKVSF-9 is an early maturing variety (80-85) days. It had $21 \%$ higher seed yields and 22\% higher oil content than Modern. Ojha \& Roy (1998), Lokendra et al. (2000), Seneviratne et al. (2004b), Yadav et al. (2004), Muhammad and Latafat (2004), Khulbe et al. (2005) and Gowda \& Seetharam (2008a) reported the similar results.

Our results indicate that the three methods of selection, per se, H.S and T.C recurrent selection are effective in improving the yield and its component of the population Giza $_{102}$ of sunflower; and the best one was per se and last one was Top cross selection. 


\section{REFERENCE}

Allard R. W. (1960). Principals of Plant Breeding. John Wiley and Sons, Inc. London.

A. O. A. C. (1980). Association of Difficial Agricultural Chemists. Official and Tentaive methods of analysis of the Association Agricultural. Chemists $6^{\text {th }}$ ed., Washington, D.C., U. S. A.

Biswas B. K., Kadir M., Alam M. S., Khan A. S. M. M. R. and Amin M. R. (1996). Selection index based on genetic parameters and character association in sunflower (Helianthus annuus L.). Journal of the Asiatic Society of Bangladesh Science, 22(2): 171-177.

Fehr W. R. (1987). Principles of Cultivar Development. 1: Theory and Technique. Macmillan Publishing Company Inc. New York.

Goksoy A. T. (1999). A study of some agronomical characteristics of synthetic varieties obtained from inbred lines of sunflower (Helianthus annuus L.). Turkish Journal of Agriculture \& Forestry, 23 (Supp2): 349-354.

Gowda J. and Seetharam A. (2008a). Response to mass and S1 selection for autogamy, seed yield and oil content in sunflower populations (Helianthus annuus L.). Helia, 31(48): 101110.

Gowda J. and Seetharam A. (2008b). Effect of different selection methods on character association in derived populations of sunflower. Crop Research Hisar, 36(1/3): 252257.

Khulbe R. K., Roy D. and Yadav V. K. (2005). Study of changes associated with recurrent half-sib selection in population of sunflower (H. annuus L.). Agricultural Science Digest, 25(1): 15-18.

Lokendra K., Singh M. and Sheoran R. K. (1997). Inheritance of achene yield and its components in a sunflower population. Journal of Oilseeds Research, 14(2): 168-171.
Lokendra K., Mahendra S., Subhadra and Sheoran R. K. (2000). Relative selection efficiency in sunflower. Indian Journal of Genetics \& Plant Breeding, 60(2): 197-200.

Luduena P., Mancuso N. and Gonzalez J. (1992). Response to recurrent selection for oil content in three sunflower populations. Proceedings of the 13th International Sunflower Conference Volume 2, Pisa, Italy, 7-11 September 1992. 1113-1117.

Mayo O. (1989). The Theory of Plant Breeding. Clarendon Press, Oxford.

Muhammad U. and Latafat P. (2004). Evaluation of sunflower hybrids for seed and oil yield for commercial cultivation in NWFP. Indus Journal of Biological Sciences, 1(3): 248-252.

Ojha, O. P., and D. Roy. 1998. Selection index in biparental population of sunflower (Helianthus annuus L.). Haryana Agricultural University Journal of Research, 28(4) 169174.

Putt E. D. (1962). The value of hybrids and synthetics in sunflower seed production. Canadian Journal Plant Science, 42: 488-500.

Putt E. D. (1966). Heterosis, combining ability and predicted synthetics from a diallel cross in sunflower ( $H$. annuus L.). Canadian Journal Plant Science, 46: 59-67.

Seneviratne K. G. S., Ganesh M., Ranganatha A. R. G., Nagaraj G. and Devi K. R. (2004). Response to selection for seed yield and yield attributes in sunflower (Helianthus annuus L.). Journal of Oilseeds Research, 21(1): 158-159.

Shabana R. 1990. Performance of a new synthetic sunflower stock developed from local and introduced germplasm and further improvement via population improvement method. Helia, 13(13): 11-16.

Syed W. H., Syed S. M. and Shahida H. (2004). Variability for agronomic traits in sunflower random-mating populations: correlations, estimated gains from selection, and correlated responses to selection. Helia, 27(41): 85-97. 
Weginwar D. G., Lande S. S., Deshmukh S. V., Patil V. N., Kshirsagar A. R. and U. B. Men. (1998). PKVSF-9: a new variety of sunflower. Annals of Plant Physiology, 12(1): 67-69.
Yadav V. K., Roy D. and Khulbe K. K. (2004). Studying changes in populations undergoing recurrent $\mathrm{S}_{1}$ selection in sunflower (Helianthus annuus L.). Journal of Oilseeds Research, 21(1): 148-151.

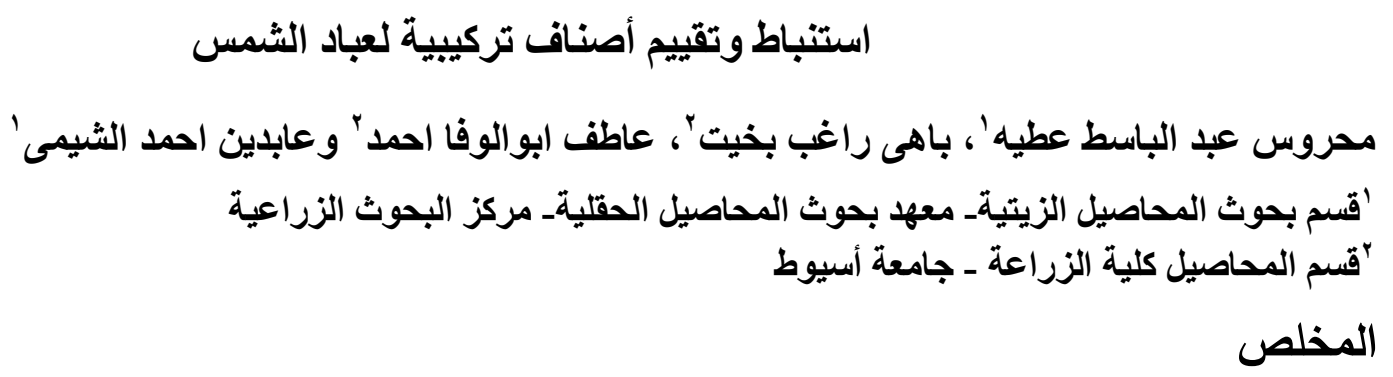

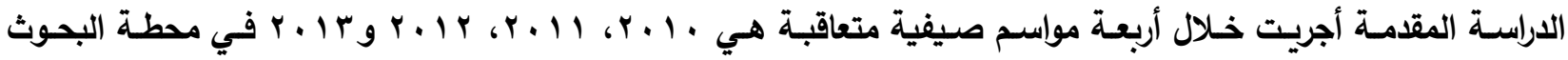
الزراعية بشندويل. تهدف هذه الدراسـة أساسـا إلى تحسين عشيرة جيزة ب ـ 1 مـن عباد الشمس من خـلال استتباط أصناف تركيبية عن طريق الانتخاب الدورى لعائلات الجيل الذاتي الأول (S)، عائلات الإخوة غير الأشقاء (H.S) وعائلات الهجن

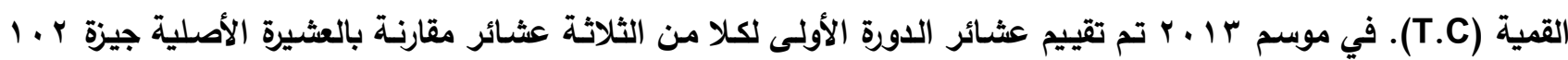
والصنف القياسى سخا به في محطتى البحوث الزراعية بثندويل وأسيوط بمركز البحوث الزراعية في تصميم قطاعات كاملـة العشوائية من ثلاث مكررات في الموقعين وذلك لقياس التقدم المشـاهد من الانتخاب. سجلت القياسـات على صفات عدد الأيام من الزراعة حتى • ه\% تزهير، عدد الأيام من الزراعة حتى النضج، طول النبات، قطر النبات، قطر القرص، وزن الـ . . 1 بذرة، محصول النبات الفردى، محصول القطعة التجريبية ونسبة الزيت في البذور • وجد من تحليل التباين أن هناك اختلافات عالية

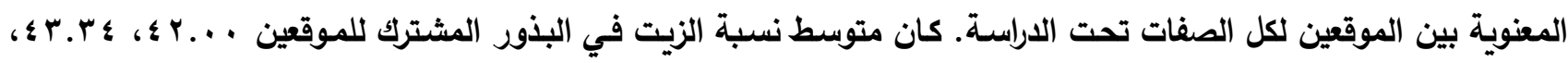

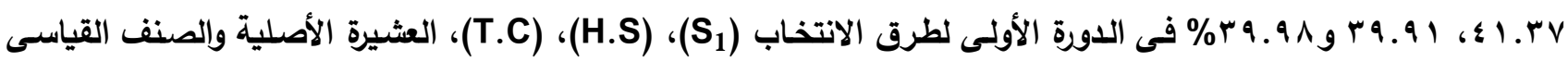
على التوالي. الاختلافـات بـين طرق الانتخـاب الثلاثـة كانت معنويـة مـا عدا بين (S1) و(T.C) فكانت غير معنويـة، لكن الاختلافات بين الدورة الأولسى، العشيرة الأصلية والصنف القياسى كانت قد زادت بلرجـة معنويسة، فيمـا عدا بين الدورة الأولى (T.C)

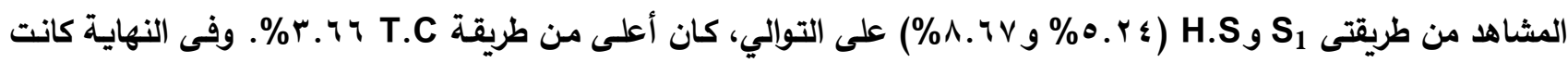

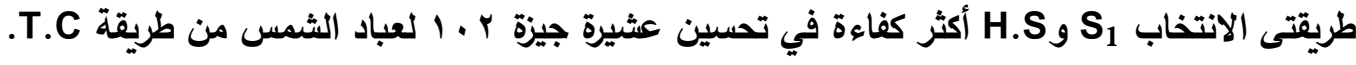

